\title{
The Impact of School Leadership and Teacher Professionalism on Teacher Success at SMA Negeri in the East Baturaja Sub-District
}

\author{
Meirita Afrianti ${ }^{*}$,, Syarwani Ahmad ${ }^{2}$, Yessi Fitriani ${ }^{2}$ \\ ${ }^{1} S M A$ Negeri $4 \mathrm{OKU}$, South of Sumatera, Indonesia \\ ${ }^{2}$ Universitas PGRI, Palembang, Indonesia \\ *Corresponding author. Email: meiritaafrianti6@gmail.com
}

\begin{abstract}
The purpose of this work is to evaluate: (1) the impact of leadership on the performance of state high school teachers in East Baturaja District; (2) the impact of teacher professionalism on the performance of SMA Negeri teachers in East Baturaja District; and (3) the impact of school principal leadership and teacher professionalism on the performance of public high school teachers in East Baturja District. This study's population consists of SMA Negeri teachers in the Baturaja Timur District. Questionnaires and documentation are two tools for collecting data. The SPSS For Windows Version 21 software application help program was used in the study data analysis technique. The findings of this study show that: (1) there is an effect of principal leadership on the performance of public high school teachers in East Baturaja District, with a 24.7 percent influence contribution; (2) there is an effect of teacher professionalism on the performance of state high school teachers in East Baturaja District, with a 17.5 percent contribution; and ; (3) There is a 33.4 percent impact contribution of principal leadership and teacher professionalism on the success of SMA Negeri teachers in East Baturaja District.
\end{abstract}

Keywords: Principal, Teacher Professionalism, Teacher Performance

\section{INTRODUCTION}

Becoming a quality teacher is a teacher who is able to make learning tools, manage learning, be able to develop himself or follow the development of the world of education so as not to miss information and master teaching materials in accordance with the field they do. To become a teacher must have certain qualifications or competencies [1]. Since the key role of the teacher is to plan, organize, execute, and assess learning, the teacher is one of the components of teaching and learning activities and has a position that determines the success of learning. Aside from that, the teacher's role in the teaching and learning process is very strategic and definitive. Strategic because the teacher decides the depth and width of the subject matter, definitive because the teacher sorts and selects the teaching content to have been provided [2]. A teacher is an occupation whose status or role necessitates specialized knowledge. Teachers' responsibilities as a discipline include educating, teaching, and training. Educating means instilling ideals in children, teaching means advancing science and technology, and training means improving student's knowledge [3].

Teachers are educators whose main task is to teach, in the sense of developing the realm of creativity, feeling and the will of students as the implementation of the ideal concept of education. Teacher personality characteristics include: cognitive flexibility, and psychological openness. We hope that teachers are able to compete and work professionally [4].

Teacher competence is the ability and authority of teachers to carry out their profession, while professionalism means special qualities and behaviors that are characteristic of professional teachers, Teachers must also be capable of carrying out teaching and learning activities, an integral and reciprocal activity between teachers and students in instructional situations [2].

A teacher is an occupation whose status or role necessitates specialized knowledge. Teachers' responsibilities as a discipline include educating, teaching, and training. Educating entails instilling life principles, while teaching entails continuing and improving science and technology, and preparation entails instilling student skills [3].

Teachers are educators whose main task is to teach, in the sense of developing the realm of creativity, feeling and the will of students as the implementation of the ideal concept of education. Teacher personality 
characteristics include: cognitive flexibility, and psychological openness. We hope that teachers are able to compete and work professionally [4]

Teacher professionalism is largely determined by management operations at the school level. The development of national education is a joint effort of all components of the government and society. Education can give birth to educated people who have an important role in social transformation in society [5].

According to Zahroh [2], success is a representation of how an individual establishes their achievement targets in general. A good teacher works with meticulous preparations in order to produce the desired results. Based on the information obtained, learning activities at SMA Negeri 1 OKU, SMA Negeri 4 OKU and SMA Negeri $5 \mathrm{OKU}$, the learning activities are carried out from 07.00 WIB to 14.45 WIB, plus extracurricular activities which are held at 14:45 WIB to 16:25 WIB WIB.

The school principal strives to give the best for the success of students in the learning process, including providing learning facilities, such as sports equipment, and art studio activities so that the learning process is carried out as expected. In the learning process assisted by teaching and education staff as many as 44 teachers consisting of 36 civil servant teachers and 8 honorary teachers, with a total of 665 students and 21 study groups consisting of 9 (nine) class X (ten) study groups, 7 (seven) study groups for class XI (eleven), and 5 (five) study groups for class XI (Twelve).

The facilities owned to support the teaching and learning process at SMA Negeri 4 OKU include 21 local learning rooms, library room, physics laboratory room, biology laboratory room, laboratory room, BP room, UKS room, student council room, places of worship, Principal's Room, Deputy Principal's Room, Teacher's Room, several toilets, school fields, sports facilities such as volleyball, badminton, football, table tennis, musical instruments for the arts such as drums, guitars, sound system, ketipung, organ, flute harmonica and pianica.

In the learning process the principal performs his duties as a leader to provide direction to teachers to always improve professionalism as an educator. However, so far the teacher still conveyed that the learning process rarely used the media of teaching aids, besides that the teacher of the discipline of teachers who taught was not linear from the subject area being taught. Recognizing the significance of the principal's leadership0 in carrying out his duties as a leader who is truly fair towards his subordinates, especially the problem of teacher performance, of course a school principal seeks to improve teacher performance, and teachers can appreciate himself for supporting the performance of the principal so that there is reciprocity, which provides mutual motivation which is better, and can carry out their duties with full responsibility, especially the leadership of the principal in improving the performance of teachers with good performance. Besides that, teacher professionalism has not indicated the real thing, in other words, the professionalism of teachers has not shown the expected professionalism. This certainly affects the performance of the teacher itself. The principal has tried and made efforts to improve teacher professionalism and teacher performance by sending teachers to take part in training, attend seminars and KKG. So that the knowledge and understanding of teachers in teaching can be even better. The school principal also explained that there were still teachers who were not disciplined in carrying out their duties, such as arriving late, some who were absent for reasons of family matters, there were also teachers who taught through lectures and assignments, sometimes without giving explanation first. In other words, teacher professionalism is not optimal, and teacher performance needs to be improved again. Starting from the above problems, the researcher wanted to find out more about the leadership applied by the principal in SMA Negeri Baturaja Timur District in improving the quality of teacher teaching and the quality of the teacher itself through research with the title, " The Impact of School Leadership and Teacher Professionalism on Teacher Success at SMA Negeri in the East Baturaja SubDistrict".

Performance is defined as a person's means, behavior and abilities [2]. According to Naim [6], performance is described as a person's achievement in a specific field or skill, in charge of the work or duty assigned by bosses effective and efficient manner. Furthermore, his explained which success is the skill individual innovative to do a task, so that their job successes in achieving goals can be seen.

Rusyan [7] suggests that teacher performance is bringing out the student learning both in and out of the classroom, in addition to other tasks such as focusing on school management and learning administration, providing instruction and resources to students, and conducting evaluations. Zahroh [2] defines success as a result of a person's overall approach to setting achievement goals.

Leadership can be defined as the ability / intelligence to encourage a number of people (two or more people) to work together in carrying out activities that are directed at common goals [8]. Leadership in the field of education also means that leaders must have skills in influencing, encouraging, guiding, directing, and mobilizing others who are related to the implementation and development of education and teaching or training so that all activities can run effectively and efficiently which in turn will achieve educational and teaching goals that have been set [9].

The principal, as a policymaker, will contribute to the achievement of full goals in order to increase the standard of education in his school, which would, of course, have an effect on the quality of students' 
graduates, enabling them to boast and plan for a bright future [3].

Based on the above definition, the researchers can conclude that the principal is a professional or instructor who is given the role of leading a school where the school is a place of interaction between teachers who offer lessons and students who receive lessons, parents as sources of hope, graduate users as sources of happiness, and the general public as a source of pride. Argues that trained teachers must possess teacher knowledge gained through teacher education [11]. Teacher competence is obtained through what is known as professionalization, which occurs both before and after a person joins a career (preservice training or pre-service) (in-service training). Explains that a professional is a person who earns a wage or salary for what he does, whether it is done perfectly or not [12]. As a result, it is obvious that teachers must possess unique skills, namely abilities that are not available to non-teachers. Professional teachers, according to this concept, are teachers who can handle themselves in carrying out daily tasks. Professional teachers are educators who have the knowledge and skills needed to carry out instructional and teaching activities. Based on the above, the authors conclude that teacher professionalism is a field of work owned by someone who has completed a level education (SPG, D.III, S1, $\mathrm{S} 2$, and S3) and is a specialist in that field [13].

\section{METHODS}

According to Arikunto [14], the study method is a scientific method for collecting data that has clear reasoning, analytical, and systematic characteristics. Quantitative research methods are research methods focused on the theory of positivism that are used to study particular populations and samples. As a consequence, the tool used in this analysis is quantitative with a survey approach [15].

The survey approach is used to collect data on natural (not artificial) sites, but researchers treat data collection by distributing questionnaires, surveys, organized interviews, and so on (treatment is not as in experiment). According to the above definition, the research method used in this study is a quantitative method with a survey approach [24].

\section{RESULTS AND DISCUSSION}

Based on the findings of this study's instrument validity trials, which included (1) testing the principal leadership questionnaire instrument with a total of 20 statement items; (2) a questionnaire instrument for teacher professionalism with a total of 20 statement items; and (3) a questionnaire instrument for teacher success with a total of 25 statement items.

The questionnaire was given to teachers outside the research sample with the number of teachers who were tested for this questionnaire were 36 teachers, with the option of choice of answers using a Likert scale, namely: (1) always (SL) with a value of 4, (2) Often SR) with a value of 3, (3) Rarely (JR) with a value of 2, (4) Never (TP) with a value of 1.

Based on the results obtained through the trial of the principal's leadership questionnaire with a total of 20 statement items, the results were> 0.329 with a significance level of $5 \%$, and it was stated that the results of the questionnaire distribution were all valid, so that they could be included in further research (data from the test results can be seen in the attachment).

Supported by the findings obtained through the test of the teacher professionalism questionnaire, a total of 20 statements were obtained $>0.329$ with a significance level of $5 \%$, and it was stated that the results of the questionnaire distribution were all valid, so that they could be included in further research (test result data can be seen in the attachment).

Derived from the findings obtained through the questionnaire test of the teacher's performance with a total of 25 statement items, the results were $>0.329$ with a significance level of $5 \%$, and it was stated that the results of the questionnaire distribution were all valid, so that they could be included in further research (data from the test results can be seen in the attachment).

Based on analysis of the reliability calculation of the discipline questionnaire instrument, the teacher work motivation questionnaire instrument, the teacher performance questionnaire instrument, it is known that the results of the reliability calculation of the discipline questionnaire instrument obtained a value of $0.854>0.6$, the results of the calculation of the principal's leadership instrument obtained a value of $0.832>0.6$, the results of the calculation of the teacher performance questionnaire instrument obtained a value of $0.848>0.6$. Thus, it can be stated that all variables have a Cronbach's Alpha coefficient> 0.6 so that it can be said that all measurement concepts of each variable from the questionnaire tested are reliable, which means that the questionnaire instrument that is distributed and used in this study is a feasible questionnaire. to proceed to the next research (data on reliability test results can be seen in this appendix).

\section{CONCLUSION}

The findings of this study show that: (1) there is an effect of principal leadership on the performance of public high school teachers in East Baturaja District, with a 24.7 percent influence contribution; (2) there is an effect of teacher professionalism on the performance of state high school teachers in East Baturaja District, with a 17.5 percent contribution; and ; (3) There is a 33.4 percent impact contribution of principal leadership and teacher professionalism on the success of SMA Negeri teachers in East Baturaja District. 


\section{ACKNOWLEDGMENT}

Our deepest gratitude goes to Teachers in SMA Negeri 4 OKU, Chancellor of Palembang PGRI University, Director of the Postgraduate Program of PGRI Palembang University and the Education Management Study Program of PGRI Palembang University, who have supported us in doing this extraordinary thing. This project is funded independently. We also want to thank our Education Management friends who helped us a lot in a short time frame to complete this project.

\section{REFERENCES}

[1] Trianto. (2012). Introduction to Educational Research for the Development of the Educational Profession and Educational Personnel. Jakarta: Kencana Prenada Media Group.

[2] Zahroh, A. (2015). Building the Quality of Learning through the Dimensions of Teacher Professionalism. Bandung: Yrama Widya.

[3] Kurniasih, I. (2017). Pedagogic Competencies, Theory and Practice for Improving Teacher Performance and Quality. Jakarta: Kata Pena.

[4] Sukadi. (2016). Teachers and the Future. Jakarta: Rajawali Press.

[5] Mulyasa. (2013). Principal Management and Leadership. Jakarta: Bumi Literasi.

[6] General Indonesian Dictionary. (2013). Definition of Principal. Jakarta: Balai Pustaka.

[7] Rusyan. (2016). Teacher Performance Improvement Management. Strategy Concept and Implementation. Bandung: Rosdakarya Muda.

[8] Nawawi, H. (2016). Leadership makes Organizations effective. Yogyakarta: Gadjah Mada Press.

[9] Wahyudi. (2012). Leadership of Principals in Learning Organizations. Bandung: Alfabeta.

[10] Sani, B. (2017). Pedagogic Competencies, Theory and Practice for Improving Teacher Performance and Quality. Jakarta: The word Pena

[11] Kristiawan, M., Safitri, D., \& Lestari, R. (2017). Educational Management. Yogyakarta: Deepublish.

[12] Yamin, M. (2017). Quality Management of Educational Curriculum. Jakarta: Rajawali Press.

[13] Bafadal, I. (2014). Management of Quality Improvement of Primary and Secondary Schools from Centralization to Decentralization. Jakarta: Earth Literacy.

[14] Arikunto, S. (2010). Research Procedure A Practice Approach. Revised Edition. Jakarta: Rineka Cipta.
[15] Sugiyono. (2015). Educational Research Methods, Quantitative Approaches, Qualitative and R \& D. Bandung: Alfabeta. 